\title{
Carotenoid Extraction from Locally and Organically Produced Cereals Using Saponification Method
}

\author{
Abrar Hussain ${ }^{1, *}$, Hans Larsson ${ }^{2}$ and Eva Johansson $2, *$ (D) \\ 1 Department of Biosciences, Sahiwal Campus, COMSATS University Islamabad, Punjab 57000, Pakistan \\ 2 Department of Plant Breeding, The Swedish University of Agricultural Sciences (SLU), P.O. Box 101, \\ 23053 Alnarp, Sweden; Hans.larsson@slu.se \\ * Correspondence: Abrar.Hussain@cuisahiwal.edu.pk (A.H.); Eva.Johansson@slu.se (E.J.)
}

Citation: Hussain, A.; Larsson, H.; Johansson, E. Carotenoid Extraction from Locally and Organically

Produced Cereals Using

Saponification Method. Processes 2021,

9, 783. https://doi.org/10.3390/

pr9050783

Academic Editors: Zongbi Bao and Qianqian Xu

Received: 15 April 2021

Accepted: 26 April 2021

Published: 29 April 2021

Publisher's Note: MDPI stays neutral with regard to jurisdictional claims in published maps and institutional affiliations.

Copyright: (C) 2021 by the authors. Licensee MDPI, Basel, Switzerland. This article is an open access article distributed under the terms and conditions of the Creative Commons Attribution (CC BY) license (https:// creativecommons.org/licenses/by/ $4.0 /)$.

\begin{abstract}
Carotenoids are important phytochemicals contributing nutritional health benefits in the human diet, with a significant contribution from cereals as one of the major food component around the world. Different methods have been described and adopted for the extraction and isolation of carotenoid compounds. Saponification can be seen as an option for carotenoid extraction from cereals as it converts retinol esters to retinol and removes other abundant compounds such as triglycerides. Extraction of carotenoids content of locally adapted and organic cereals have been limitedly investigated and was, therefore, evaluated in the present study, with a specific aim to understand genotypic and local cultivation effects and interactions. Therefore, 17 diverse cereal genotypes of local origin were grown organically in four localities and evaluated for carotenoid content and composition by HPLC. The results showed a large variation in content and composition of carotenoids in locally adapted and organically grown cereal genotypes, with lutein as the dominating type in wheat and rye, while zeaxanthin was the dominating type in barley. High-level genotypes showed values $(9.9 \mathrm{mg} / \mathrm{kg}$ of total carotenoids) similar to the highest values previously reported in specific types of wheat. The barley genotypes showed relatively high stability in carotenoids content within and between cultivation locations, while large interactions were found with the cultivation location for the rest of the genotypes, indicating their local adaptation. The local adaptation of the cereal genotypes evaluated contributes large opportunities for local production of high value, highly nutritious food products, while the direct value of these genotypes for conventional plant breeding for varieties performing similar over broad environmental ranges, are more limited.
\end{abstract}

Keywords: organic wheat genotypes; saponification; carotenoids; lutein content; environmental effects

\section{Introduction}

Cereals are the most important type of crops in terms of quantity available for food production to the human population [1-3]. The three major crops contributing to human food are wheat, maize, and rice, all three belonging to the cereal group of crops [1]. The total harvest of these three crops, are 2.5 billion tonnes, which contributes $42 \%$ and $37 \%$ of the human calorie and protein supply, respectively, thereby making these crops outstanding for human food security [4]. However, within the Nordic hemisphere, only wheat among these three can be grown, but other cereals such as barley, rye, and oats are instead making an important contribution to the cereals share in the human diet [5]. Similarly to other regions of the world, locally adapted cultivars have been developed in the Nordic regions, of crops traditionally in use [6]. Such traditionally grown cultivars (landraces) are often adapted to the local environment in which they have been grown, including an adaptation to the local climatic and soil conditions [7]. Recent studies have also indicated that some traditionally grown cultivars have a good capability for uptake and transportation of, e.g., minerals to the grain, resulting in a high nutritional value of the grains $[8,9]$.

Food from organically produced crops is increasingly desired from consumers, mainly due to an increasing concern for the threat to the global environment and human health 
issues [10,11]. Concerned consumers are assuming organic production to contribute to less chemicals being used in agriculture, to increased biodiversity in organic production systems and to the production of food that contribute with human health attributes [11,12]. Although the results differ in various studies, some indications are available of organically produced food being richer in minerals and phytochemicals than conventionally produced food $[8,9,11]$.

Cereals contain a number of phytochemicals [13], carotenoids being one of those, present in various amounts in cereals [14,15]. Despite being present in relatively low amounts in cereals, the generally high intake of cereals as being the staple in many countries, make cereals an important contributor of carotenoids in the human diet [16]. Cereals are known to be particularly rich in the carotenoids lutein and xeazanthin [17-20], where previous results have indicated that $40 \%$ of the daily requirement of lutein can be obtained from wheat [16]. Both mentioned compounds contribute positively to human health benefits, as they are known to promote the health of skin and eyes and to reduce the risk of cardiovascular diseases [21,22].

Analytical methods used for the extraction, isolation, and quantification of carotenoids are an important factor for accurate estimation of carotenoid compounds [23]. In fact, these compounds are easily degraded by different extraction procedures because of varying affinity between solvents and carotenoid compounds [24]. Due to wide range of polarity among carotenoid compounds different solvents are used, e.g., xanthophylls are extracted by polar solvents, i.e., alcohols and acetones, whereas carotene are extracted by nonpolar solvents [23]. Therefore, content of carotenoid compounds is often underestimated due to extraction procedure and solvent used. Due to these circumstances, saponification may be a suitable option for carotenoid extraction from cereals as it converts retinol esters to retinol and remove the other abundant compounds such as triglycerides. Furthermore, chlorophyll in samples is also destroyed through saponification as it interferes with spectrometric measurements [25].

A number of studies have evaluated the content and composition of carotenoids in cereals [26-30] although the majority of these studies have focused on wheat. Knowledge related to impact of organic production and local adaptation for nutritional value when it comes to carotenoids of cereals is basically lacking. Thus, despite the fact that consumers are willing to cover extra cost for (i) local production, (ii) organic production, and (iii) food from traditional varieties, with the expectation of a healthier food intake [30,31], few scientific studies have been undertaken to evaluate content and composition of nutritional components in such food related crops.

The aim of the present study was to evaluate the content of various carotenoids in locally adapted and organically produced cereals. Effect of genotype and locality on the content, as well as stability over and within locations, were evaluated in order to understand mechanisms for variation in content of carotenoids in traditionally grown cereals in Sweden. Due to recent interest in cereal carotenoids, the importance of wheat and other cereals has been increased during the last few years. Thus, the present study also focused on the role of $\beta$-carotene and $\beta$-cryptoxanthin in general and lutein in particular with respect to human health and daily intake contribution from different cereals.

\section{Materials and Methods}

\subsection{Chemicals}

Standards of $\alpha$-carotene, $\beta$-carotene and lutein were obtained from Sigma (Schnelldorf, Germany). $\beta$-cryptoxanthin and zeaxanthin were purchased from CaroteNature (Lupsingen, Switzerland). The stock solution for the standards was prepared at the concentration of $50 \mu \mathrm{g} / \mathrm{mL}$ of $\mathrm{n}$-hexane and stored in the dark at $-20{ }^{\circ} \mathrm{C}$. Suitable volume of each stock solution was used to prepare a working solution. 


\subsection{Samples}

A total of 17 genotypes from diverse groups, i.e., landraces, old cultivar and primitive wheat were used in the present study (Table 1). These genotypes were grown in organic trials at Ekhaga ( $59^{\circ} 49^{\prime} 57^{\prime \prime} \mathrm{N}, 17^{\circ} 48^{\prime} 58^{\prime \prime}$ E), Krusenberg ( $59^{\circ} 44^{\prime} 8^{\prime \prime} \mathrm{N}, 17^{\circ} 38^{\prime} 58^{\prime \prime}$ E), Alnarp $\left(55^{\circ} 39^{\prime} 27^{\prime \prime} \mathrm{N}, 13^{\circ} 04^{\prime} 51^{\prime \prime} \mathrm{E}\right)$, and Gotland $\left(57^{\circ} 35^{\prime} 52^{\prime \prime} \mathrm{N}, 18^{\circ} 26^{\prime} 50^{\prime \prime} \mathrm{E}\right)$ in Sweden. At maturity, the cereals were harvested, threshed, and transported to the department in Alnarp where the grains were kept in a seed storage room (dark, dry, and cool $-8^{\circ} \mathrm{C}$ ). Before analysis, the grains were freeze-dried and about six grams of each grain sample was milled to whole meal flour for $20 \mathrm{~s}$ by a laboratory mill (Yellow line, A10, IKA-Werke, Staufen, Germany). Afterwards, carotenoids were extracted from the whole meal flour.

Table 1. Name, type of cereal, and origin (year released, NGB number at Nordgen and if selections have been made on the material) of cereals used in the present study.

\begin{tabular}{cccc}
\hline Name & Type & Cereal Type & $\begin{array}{c}\text { Origin } \\
\text { Year Released and NGB Number }\end{array}$ \\
\hline Algot & Spring wheat & Old cultivar & 1953, NGB11611 \\
Atle & Spring wheat & Old cultivar & 1936, NGB7455 \\
Atson & Spring wheat & Old cultivar & 1954, NGB7460 \\
Aurore & Spring wheat & Old cultivar & 1929, NGB9690 \\
Dacke & Spring wheat & Old cultivar & 1990, NGB9955 \\
Dalarna & Spring wheat & Landrace & NGB6673, selection \\
Diamant brun & Spring wheat & Old cultivar & 1938, NGB6681, selection \\
Ella & Spring wheat & Old cultivar & 1950, NGB6683 \\
Gengel & Naked 2-row barley & Landrace Czech republic & From Czech growers \\
Jusso & Spring rye & Finnish landrace & From finish growers \\
Kärn 1 & Spring wheat & Old cultivar & 1947, NGB7458 \\
Naket 6-r & Naked 6-row barley & Selection & Diverse origin from Gene bank \\
Naket korn 2rads & Naked 2-row barley & Selection & Diverse origin from Gene bank \\
Naket korn 6rads & Naked 6-row barley & Selection & Diverse origin from Gene bank \\
Ölands & Spring wheat & Landrace & NGB 4798, selection \\
Prins & Spring wheat & Old cultivar & 1962, NGB6688 \\
Våremmer & Spring wheat & Primitive & NGB4499, selection as spring wheat \\
\hline
\end{tabular}

\subsection{Extraction by Saponification}

Saponification was carried out for the extraction of carotenoids using the method described by Fratianni et al. [32] with modifications of Hussain et al. [16,33]. Briefly, $1 \mathrm{~g}$ of whole meal flour was weighed into a screw cap Teflon tube and saponified with $2.5 \mathrm{~mL}$ of ethanol pyrogallol $(60 \mathrm{~g} / \mathrm{L}), 1 \mathrm{~mL}$ sodium chloride $(10 \mathrm{~g} / \mathrm{L}), 1 \mathrm{~mL}$ ethanol $(95 \%)$, and $1 \mathrm{~mL}$ potassium hydroxide $(600 \mathrm{~g} / \mathrm{L})$. The tubes were placed in a $70{ }^{\circ} \mathrm{C}$ water bath for $30 \mathrm{~min}$ and mixed every $10 \mathrm{~min}$ during saponification. Afterwards, the tubes were cooled in an ice-water bath and $7.5 \mathrm{~mL}$ of sodium choloride and n-hexane/ethyle acetate (9:1) was added. Then organic layer was separated by centrifuging at $1500 \mathrm{rpm}$ for $5 \mathrm{~min}$. Two additional extractions were carried out by adding $5 \mathrm{~mL}$ of $\mathrm{n}$-hexane/ethyle acetate (9:1) in each extraction. The organic layer was evaporated to dryness and residue was dissolved in $2 \mathrm{~mL}$ of $\mathrm{n}$-hexane. Each whole meal flour sample was replicated three times.

\subsection{HPLC Analysis}

Carotenoid compounds were separated by normal phase HPLC according to Panfili et al. [34] with some modifications. Separation was achieved by $250 \times 4.6 \mathrm{~mm}$ i.d., $5 \mu \mathrm{m}$ particle size, Phenomenex LUNA Silica column. The mobile phase was n-hexane/isopropyl alcohol (5\%) and flow rate was $1.5 \mathrm{~mL} / \mathrm{min}$. A fluorescence detector set in the range of $350-500 \mathrm{~nm}$ was used for the detection of the carotenoids and peaks were detected at $450 \mathrm{~nm}$. The volume of each injection was $100 \mu \mathrm{L}$. Carotenoids compounds were identified by their particular spectra and their retention time compared with respective standards. In addition, the column was reactivated after every 12 injections with a solution of $10 \%$ 
isopropyl and n-hexane $(v / v)$. A representative chromatogram of the analyses is shown in Supplementary (Figure S1).

\subsection{Data Analysis}

Analysis of variance (ANOVA), Spearman rank correlation and Principle Component Analysis (PCA) were carried out using the statistical analysis system (SAS).

Percentage of explanation (obtained from the coefficient of determination- $-\mathrm{R}^{2}$ ) of different sources (cultivar, location, and their combinations) on content of total and various types of carotenoids were calculated using a simple linear regression analysis, following the procedure described in previous investigations [9,35-37]. By linear regression analysis, an independent variable can be used to predict the value of a dependent variable, and the $\mathrm{R}^{2}$ value of a linear regression analysis predicts how well a feature (independent variable) can explain a target (dependent variable) [38]. Thus, an $\mathrm{R}^{2}$ close to 1 means that the proportion is high that the independent variable explains the dependent variable (https:/ / www.colby.edu/biology/BI17x/regression.html) (accessed on 23 March 2021) which makes it possible to select the sources that are of highest importance to determine different traits [38].

To evaluate stability of genotypes within and between localities, coefficient of variation (ratio of standard deviation to the mean) was calculated as a measure of variability. Thus, a lower coefficient of variation indicates higher stability for a genotype either within or across localities.

To secure proper HPLC results, standard solutions were run several times with different batches of samples in order to calibrate and to check the precision of the method. The results of repeated calibrations showed that carotenoid compounds were determined precisely with $C V \%$ less than 3 for $\beta$-carotene, $\beta$-cryptoxanthin, lutein, and zeaxanthin. The calibration curve was plotted between the concentration and peak areas of each carotenoid compound, i.e., $\beta$-carotene, $\beta$-cryptoxanthin, lutein, and zeaxanthin, which showed linear relationship as indicated by $\mathrm{R}^{2}$ value $>0.99$. The recovery percentage of $\beta$-carotene, $\beta$ cryptoxanthin, and lutein was $97.8 \%, 96.6 \%$, and $99.1 \%$, respectively. The limit of detection (LOD) was measured for the HPLC method and it was 0.04 ppm for $\beta$-carotene and 0.011 ppm for lutein.

\section{Results}

\subsection{Grain Carotenoid Content in Locally and Organically Produced Cereals and Genotype X} Environment Effects

The total carotenoid content in the wheat grain of locally and organically grown cereals varied between $1.96 \mathrm{mg} / \mathrm{kg}$ in the spring wheat cultivar 'Ölands' grown in Alnarp to $9.87 \mathrm{mg} / \mathrm{kg}$ in the spring wheat cultivar 'Dalarna' grown at Krusenberg (Table 2). The total carotenoid content in the evaluated barley cultivars varied from 4.83 in 'Naket korn 2rads' at Alnarp to 7.32 in 'Gengel' at Krusenberg (Table 2). The spring rye cultivar 'Jusso' showed total carotenoid content from 3.27 when grown in Ekhaga to 8.59 when grown at Krusenberg. Moreover, the different carotenoids evaluated varied widely over cultivars and localities. Contents were found for the different compounds, from 0.06 (Ölands, Alnarp) to $0.48 \mathrm{mg} / \mathrm{kg}$ (Jusso, Gotland) for $\beta$-carotene, 0.001 (Våremmer, Krusenberg) to $0.019 \mathrm{mg} / \mathrm{kg}$ (Jusso, Krusenberg) for $\beta$-cryptoxanthin, 1.56 (Ölands, Alnarp) to $8.47 \mathrm{mg} / \mathrm{kg}$ (Dalarna, Krusenberg) for lutein, and 0.33 (Ölands, Alnarp) to 4.00 (Gengel, Krusenberg) for zeaxanthin (Table 2).

\subsection{Percentage of Explanation for Variation in Carotenoids Content}

$\mathrm{R}$ square values used to explain the percentage of explanation for the different carotenoids compounds and for the total carotenoids content, clearly showed a higher degree of explanation for the cultivars analyzed as compared to the location used for cultivation. However, the combination of cultivars and localities showed clearly the highest 
percentage of variation for the compounds, which was especially valid for $\beta$-carotene and lutein, as well as for the total content of carotenoids (Table 3).

Table 2. Mean value $(\mathrm{mg} / \mathrm{kg}) \pm$ standard deviation of the different carotenoids per cultivation locality (italics) and cultivar.

\begin{tabular}{|c|c|c|c|c|c|}
\hline Locality and Cultivar & $\beta$-Carotene $\left(10^{-1}\right)$ & $\beta$-Cryptoxanthin $\left(10^{-3}\right)$ & Lutein & Zea-Xanthin & Total Carotenoids \\
\hline \multicolumn{6}{|c|}{ Ekhaga } \\
\hline Algot & $1.13 \pm 0.20$ & $4.81 \pm 0.72$ & $2.30 \pm 0.06$ & $1.12 \pm 0.25$ & $3.53 \pm 0.30$ \\
\hline Dacke & $1.94 \pm 0.01$ & $7.01 \pm 0.40$ & $3.27 \pm 0.21$ & $0.90 \pm 0.01$ & $4.37 \pm 0.20$ \\
\hline Dalarna & $3.33 \pm 0.12$ & $16.4 \pm 0.91$ & $7.63 \pm 0.16$ & $1.19 \pm 0.01$ & $9.17 \pm 0.16$ \\
\hline Diamant brun & $7.93 \pm 0.04$ & $3.06 \pm 0.11$ & $1.59 \pm 0.04$ & $0.67 \pm 0.02$ & $2.35 \pm 0.06$ \\
\hline Ella & $1.14 \pm 0.03$ & $2.80 \pm 0.27$ & $3.21 \pm 0.04$ & $1.28 \pm 0.03$ & $4.61 \pm 0.06$ \\
\hline Gengel & $2.62 \pm 0.12$ & $6.14 \pm 0.54$ & $2.49 \pm 0.11$ & $3.03 \pm 0.10$ & $5.79 \pm 0.21$ \\
\hline Jusso & $1.40 \pm 0.22$ & $4.79 \pm 0.23$ & $2.36 \pm 0.01$ & $0.73 \pm 0.06$ & $3.24 \pm 0.09$ \\
\hline Kärn 1 & $1.64 \pm 0.03$ & $4.32 \pm 0.47$ & $4.93 \pm 0.05$ & $1.09 \pm 0.02$ & $6.19 \pm 0.03$ \\
\hline Naket 6-r & $2.42 \pm 0.22$ & $4.27 \pm 0.54$ & $2.58 \pm 0.14$ & $2.76 \pm 0.23$ & $5.58 \pm 0.37$ \\
\hline Ölands & $0.76 \pm 0.02$ & $2.91 \pm 0.01$ & $1.66 \pm 0.01$ & $0.66 \pm 0.01$ & $2.40 \pm 0.02$ \\
\hline Prins & $1.48 \pm 0.10$ & $4.57 \pm 0.01$ & $4.21 \pm 0.03$ & $1.09 \pm 0.01$ & $5.45 \pm 0.03$ \\
\hline Våremmer & $0.92 \pm 0.05$ & $4.02 \pm 0.26$ & $3.45 \pm 0.13$ & $0.57 \pm 0.04$ & $4.12 \pm 0.16$ \\
\hline \multicolumn{6}{|c|}{ Krusenberg } \\
\hline Algot & $1.58 \pm 0.07$ & $3.88 \pm 0.72$ & $6.38 \pm 0.21$ & $0.98 \pm 0.01$ & $7.52 \pm 0.22$ \\
\hline Aurore & $1.42 \pm 0.04$ & $6.46 \pm 0.14$ & $5.80 \pm 0.06$ & $1.13 \pm 0.03$ & $7.08 \pm 0.08$ \\
\hline Dalarna & $2.24 \pm 0.03$ & $4.94 \pm 0.60$ & $8.14 \pm 0.44$ & $1.19 \pm 0.05$ & $9.56 \pm 0.46$ \\
\hline Diamant brun & $1.84 \pm 0.12$ & $4.83 \pm 0.22$ & $4.77 \pm 0.04$ & $1.34 \pm 0.01$ & $6.29 \pm 0.06$ \\
\hline Ella & $1.19 \pm 0.02$ & $2.03 \pm 0.01$ & $3.89 \pm 0.12$ & $1.09 \pm 0.03$ & $5.10 \pm 0.16$ \\
\hline Gengel & $2.09 \pm 0.07$ & $2.13 \pm 0.01$ & $3.06 \pm 0.12$ & $3.85 \pm 0.14$ & $7.12 \pm 0.23$ \\
\hline Jusso & $3.50 \pm 0.12$ & $16.6 \pm 2.29$ & $5.46 \pm 0.05$ & $2.63 \pm 0.06$ & $8.46 \pm 0.12$ \\
\hline Kärn 1 & $1.81 \pm 0.02$ & $6.75 \pm 1.55$ & $6.77 \pm 0.11$ & $1.11 \pm 0.16$ & $9.07 \pm 0.06$ \\
\hline Naket 6-r & $1.77 \pm 0.02$ & $1.98 \pm 0.01$ & $2.41 \pm 0.24$ & $2.95 \pm 0.07$ & $5.54 \pm 0.31$ \\
\hline Ölands & $1.93 \pm 0.07$ & $4.74 \pm 0.82$ & $4.52 \pm 0.24$ & $1.24 \pm 0.06$ & $5.97 \pm 0.31$ \\
\hline Våremmer & $1.73 \pm 0.07$ & $1.24 \pm 0.01$ & $4.14 \pm 0.14$ & $0.56 \pm 0.03$ & $4.88 \pm 0.18$ \\
\hline \multicolumn{6}{|c|}{ Alnarp } \\
\hline Atson & $2.12 \pm 0.02$ & $4.86 \pm 0.36$ & $4.62 \pm 0.01$ & $0.67 \pm 0.01$ & $5.50 \pm 0.01$ \\
\hline Diamant brun & $1.78 \pm 0.04$ & $5.06 \pm 0.28$ & $4.18 \pm 0.12$ & $0.55 \pm 0.01$ & $4.91 \pm 0.13$ \\
\hline Ella & $0.75 \pm 0.00$ & $1.29 \pm 0.01$ & $1.86 \pm 0.01$ & $1.09 \pm 0.03$ & $2.24 \pm 0.01$ \\
\hline Jusso & $2.64 \pm 0.19$ & $11.3 \pm 1.15$ & $3.74 \pm 0.16$ & $1.55 \pm 0.17$ & $5.57 \pm 0.16$ \\
\hline Naket korn 2rads & $1.84 \pm 0.10$ & $3.03 \pm 0.19$ & $2.84 \pm 0.06$ & $1.88 \pm 0.05$ & $4.90 \pm 0.12$ \\
\hline Naket korn 6rads & $2.06 \pm 0.07$ & $4.16 \pm 0.01$ & $3.18 \pm 0.06$ & $1.98 \pm 0.05$ & $5.37 \pm 0.12$ \\
\hline Ölands & $0.68 \pm 0.06$ & $1.78 \pm 0.01$ & $1.69 \pm 0.13$ & $0.36 \pm 0.03$ & $2.12 \pm 0.17$ \\
\hline \multicolumn{6}{|c|}{ Gotland } \\
\hline Atle & $2.28 \pm 0.09$ & $5.51 \pm 00.33$ & $7.21 \pm 0.52$ & $1.32 \pm 0.07$ & $8.76 \pm 0.61$ \\
\hline Dalarna & $2.74 \pm 0.15$ & $4.68 \pm 0.58$ & $5.53 \pm 0.32$ & $0.85 \pm 0.04$ & $6.66 \pm 0.37$ \\
\hline Diamant brun & $1.27 \pm 0.12$ & $5.25 \pm 0.79$ & $3.64 \pm 0.03$ & $0.81 \pm 0.01$ & $4.58 \pm 0.04$ \\
\hline Ella & $1.26 \pm 0.07$ & $2.25 \pm 0.32$ & $3.50 \pm 0.03$ & $0.92 \pm 0.01$ & $4.55 \pm 0.04$ \\
\hline Jusso & $3.68 \pm 0.96$ & $12.4 \pm 0.21$ & $4.83 \pm 0.12$ & $2.52 \pm 0.06$ & $7.73 \pm 0.09$ \\
\hline Naket korn 2rads & $1.84 \pm 0.02$ & $4.71 \pm 0.51$ & $2.28 \pm 0.03$ & $2.71 \pm 0.06$ & $5.19 \pm 0.09$ \\
\hline Naket korn 6rads & $2.60 \pm 0.03$ & $2.54 \pm 0.39$ & $2.76 \pm 0.06$ & $2.38 \pm 0.02$ & $5.41 \pm 0.05$ \\
\hline Prins & $1.90 \pm 0.02$ & $3.09 \pm 0.28$ & $4.83 \pm 0.05$ & $0.86 \pm 0.04$ & $5.88 \pm 0.06$ \\
\hline
\end{tabular}

Table 3. Percentage of explanation (obtained through the coefficient of determination (R2) from simple linear regression analysis) of cultivar (C), location (L), and their combinations (CL) on amount of different carotenoids compound and for total carotenoids content.

\begin{tabular}{cccccc}
\hline & $\beta$-Carotene & $\beta$-Cryptoxanthin & Lutein & Zeaxanthin & Total Carotenoids \\
\hline C & 62.8 & 32.3 & 48.1 & 68.6 & 37.4 \\
L & 8.15 & 0.73 & 20.2 & 6.85 & 28.8 \\
CL & 92.6 & 66.1 & 92.4 & 83.5 & 93.5 \\
\hline
\end{tabular}




\subsection{Relationship between Genotype, Environment and Contents of Different Carotenoids}

Relationships among the genotypes and environments for carotenoid content and composition was visually revealed by a principal component analysis (PCA; the first principal component explained $61.3 \%$ and the second $23.7 \%$ of the variation), clearly being able to depict the spring rye cultivar 'Jusso' with high values on the first principal component and positive value on the second principal component, except when Jusso was grown in Ekhaga. Furthermore, the barley cultivar 'Gengel' and naked barley (two and six row types) were found with positive values on the second principal component (Figure 1a). The positive value on the first principal component for spring rye is a result of a general high content of total carotenoids and especially of a high content of $\beta$-carotene in spring rye (Figure $1 b$ ). However, cultivation conditions were also able to influence the contents of carotenoids in spring rye with lower values when cultivated in Ekhaga. The positive values for the second principal component for barley is the result of high zeaxanthin values in the barley cultivars evaluated (Figure 1b). Among the spring wheats, 'Dalarna' was found with positive values on the first principal component and negative values on the second principal component independent of growing location (Figure 1a), indicating high level of lutein in this cultivar (Figure 1b). Similarly, 'Atle' from Gotland, and 'Algot', 'Aurore', and 'Kärn I' from Krusenberg showed indications of high lutein content while 'Algot' from Ekhaga was found with negative first and positive second principal component values. 'Atle' and 'Aurore' were only evaluated in one location each.

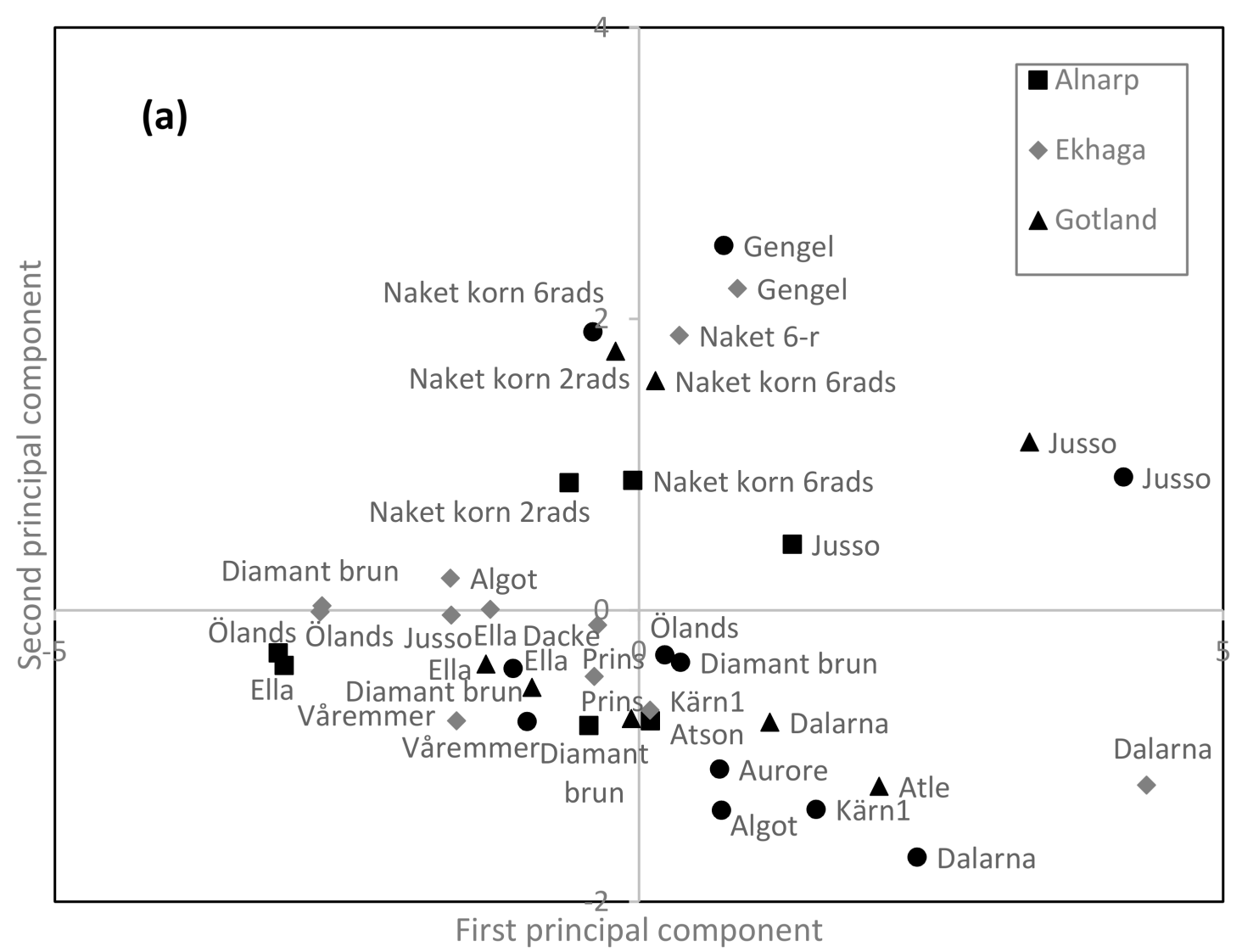

Figure 1. Cont. 


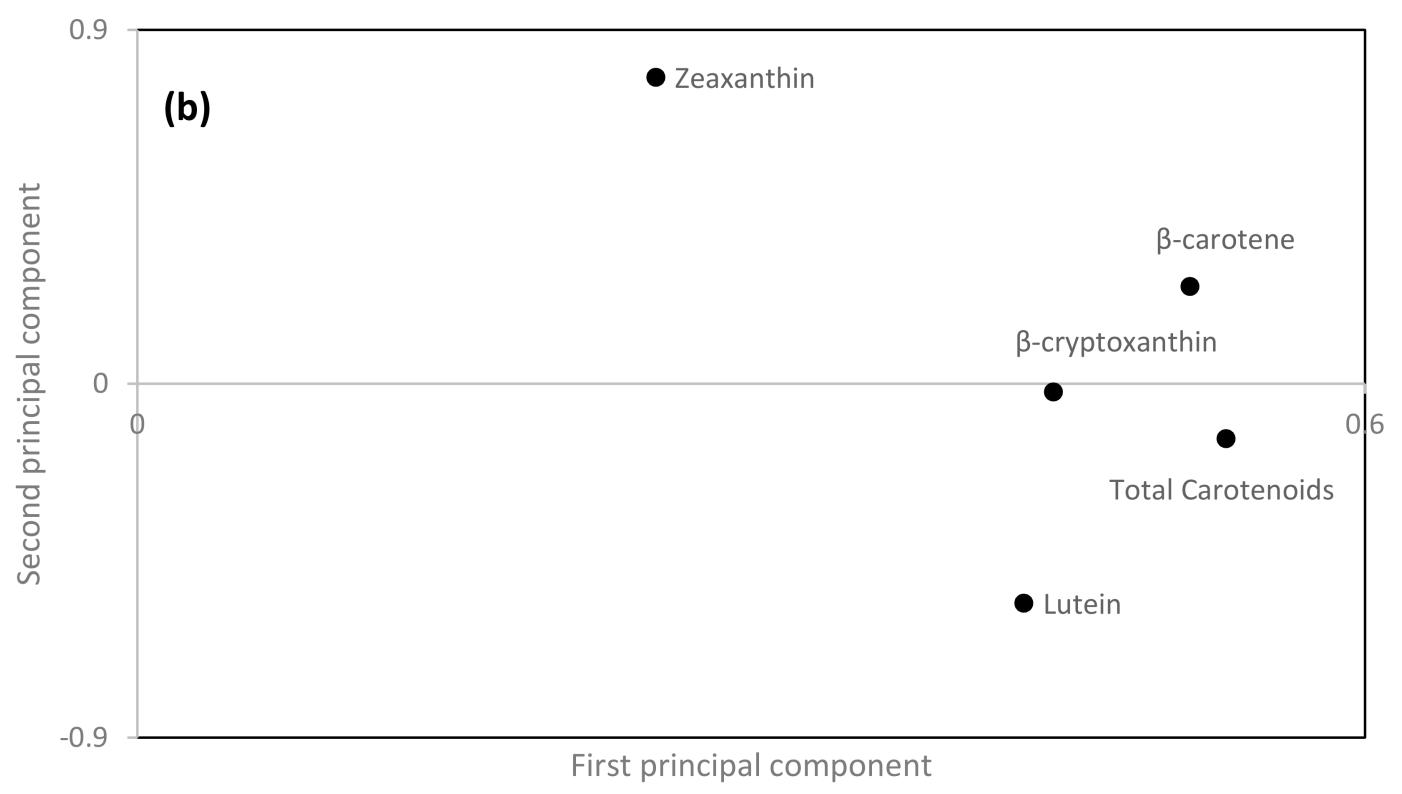

Figure 1. Loading (a) and score (b) plot from principal component analysis of carotenoid compounds and total carotenoid content in organically grown locally adapted spring cereals. First principal component explained $61.3 \%$ of the variation while the second principal component explained $23.7 \%$ of the variation.

\subsection{Stability Over Environments}

The cultivars 'Jusso' and 'Dalarna' showed the highest $\beta$-carotene levels across the localities of cultivation for these cultivars although naked barley (2- and 6-rowed) and 'Kärn I' showed the highest stability in $\beta$-carotene content over localities (Figure 2a). In Figure 2a,b, percentage of coefficient of variation explain the dispersion of data around mean concentration of carotenoid compounds. It provides a relatively simple and rapid method to understand the level of stability within and across locations of genotypes investigated in the present study. The cultivar 'Jusso' also showed the highest level of $\beta$-cryptoxanthin across localities of cultivation although the most stable cultivars over locations was found to be 'Algot', 'Prins', and 'Diamant brun', followed by the naked barley (2 and 6 rows). For lutein, the highest level was found for 'Jusso' and 'Dalarna' while highest stability was found for 'Kärn I' and 'Naket korn 2rads'. Highest and most stable content of zeaxanthin was found for 'Gengel' and naked barley (Naket 6-r) (Figure 2a).

\subsection{High Content and Stability per Cultivar within an Environment}

The highest content of $\beta$-carotene within a locality was found for 'Dalarna' grown in Ekhaga and 'Jusso' grown in Krusenberg while high and stable content was found for 'Atson' grown in Alnarp, 'Dalarna' grown in Krusenberg, and 'Naket korn 6rads' grown in Gotland (Figure 2b). 'Jusso', grown in Gotland was found with high and stable content of $\beta$-cryptoxanthin (Figure 2b). High and relatively stable content of lutein was found in 'Dalarna' grown in Ekhaga, and 'Aurore', 'Jusso' and 'Kärn I' grown in Krusenberg (Figure $2 \mathrm{~b}$ ). High and stable zeaxanthin values were found in naked barley ( 2 and 6 rows) from Alnarp, Krusenberg, and Gotland, 'Jusso' from Gotland and Krusenberg, and 'Gengel' from Krusenberg and Ekhaga (Figure 2b).

\subsection{Correlation among Carotenoids and Plant Characters}

Significant and positive correlations were found among $\beta$-carotene, $\beta$-cryptoxanthin, and Lutein, while zeaxanthin only correlated significantly and positively with $\beta$-carotene (Table 4). A positive and significant correlation was also found between straw length and content of lutein as well as between straw length and grain protein concentration. No other significant correlations among the content of carotenoids and plant characters were noted in the present study. 

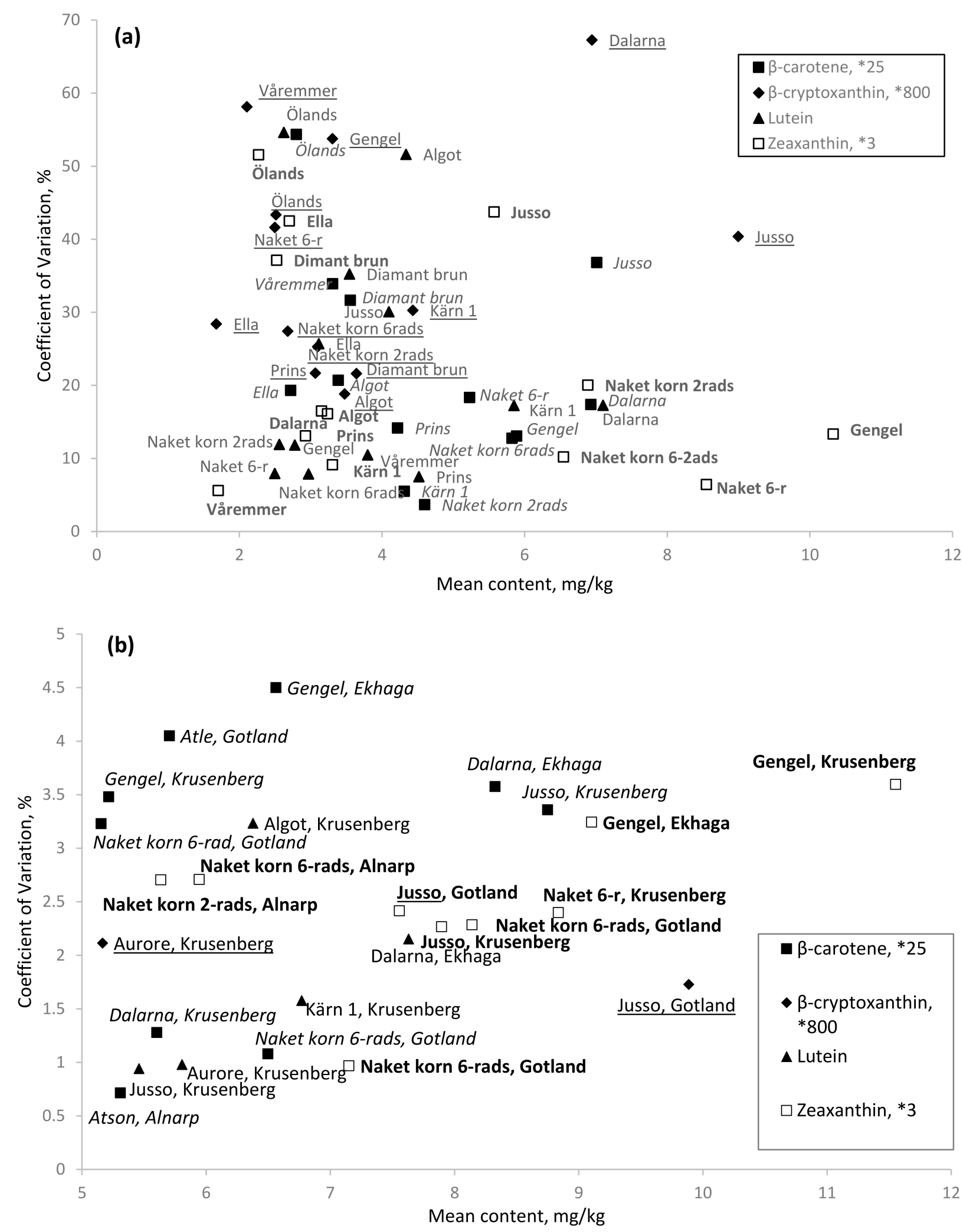

Figure 2. Mean content of carotenoid compounds and stability measured as coefficient of variation of evaluated cultivars over cultivation localities (a), and of high mean content cultivars within a specific cultivation locality (b). Multiplication numbers given after each carotenoid compound name indicate factor used to obtain similar scale of mean content for the different compounds. Italic, underlined, normal, and bold text indicate mean content of $\beta$-carotene, $\beta$-cryptoxanthin, lutein, and zeaxanthin, respectively, for the different cultivars (+locations). 
Table 4. Pearson correlation coefficients for content of various carotenoids and plant parameters of locally and organically produced cereals.

\begin{tabular}{cccccccc}
\hline & $\beta$-Cryptoxanthin & $\beta$-Carotene & Lutein & Zea-Xanthin & Yield (kg/Ha) & TKV (g) & Protein Content (\%) \\
\hline$\beta$-carotene & $0.72^{* * *}$ & & & & & & \\
Lutein & $0.47^{* * *}$ & $0.48^{* *}$ & & & & \\
Zea-xanthin & 0.20 & $0.55^{* * *}$ & -0.12 & & & \\
Yield (kg/Ha) & 0.14 & 0.09 & 0.06 & -0.16 & -0.27 & 0.29 & -0.17 \\
TKV (g) & -0.14 & -0.16 & -0.14 & 0.09 & -0.11 & $-0.69 * *$ \\
Protein Content (\%) & -0.17 & -0.09 & -0.38 & 0.06 & 0.24 & -0.28 & \\
Straw Length (cm) & 0.31 & 0.11 & $0.50^{* *}$ & -0.17 &
\end{tabular}

\section{Discussion}

The locally adapted and organically produced cereals investigated for carotenoids contents extracted through saponification showed high amounts of carotenoid compounds, although with significant differences in content among cereal type, but also among cultivars of the same type of cereal, and cultivation location had a significant impact on the content. Besides variation in mean content, the various cultivars evaluated showed large variation in stability of the content over different cultivation locations and also within the same cultivation location. Thus, the present study revealed the importance of the cultivar and its adaptation to the cultivation location in order to result in a high and stable content of carotenoids, thereby affecting human health positively.

The total carotenoid content in the cereals investigated in this study varied from 1.96 to $9.87 \mathrm{mg} / \mathrm{kg}$, with both highest and lowest content reported for landraces of wheat. Previous studies on wheat have shown large variation in carotenoid contents among wheat cultivars $[18,39,40]$, with values from 0.94 to $13.6 \mathrm{mg} / \mathrm{kg}[40,41]$, thereby the levels found in the present study correspond well with previous findings. The large variations in carotenoids content among cereal cultivars highlight opportunities to screen and produce high content batches for specific uses. The highest content of total carotenoids have previously been reported in einkorn, durum wheat, and purple wheat [28], indicating that some of the landraces of wheat evaluated here, showed high content as compared to previously reported values for wheat. Studies on carotenoid content in barley and rye are limited, with reported values of $2.25-4.54 \mathrm{mg} / \mathrm{kg}$ for barley $[14,28]$. Thus, the present study showed high levels of total carotenoid content in the evaluated barley (4.83-7.32) and rye cultivars (3.27-8.59). The high total carotenoid content reported here for locally adapted and organically grown cereals might be an effect of a relative short time from harvest to freezing and analyses of the samples. Lower values were obtained for a wheat material of similar types of landraces when a longer storage time before freezing of the samples was applied [16]. Moreover, a successful saponification may be part of the explanation of the results. Previous studies have indicated that agronomic practices may have an impact on the content of carotenoids in cereals $[28,42]$. However, large variation in the same material grown at different locations are reported here, indicating also the importance of suitable cultivation locations for specific landraces adapted to different local origins.

The composition of carotenoids varied largely among the investigated cereals. Similarly to what has been reported previously $[16,18,34,39]$, high levels of lutein were found in wheat in the present study. Lutein rich wheat cultivars, with a content of $3.7 \mathrm{mg} / \mathrm{kg}$, have previously been reported as able to contribute $40 \%$ of the human daily requirement [16], which would result in the double contribution for the cultivar (i.e., Dalarna) with the highest level in the present study. However, low content of lutein was also found in some of the wheat cultivars in the present study, e.g., in 'Ölands' grown in Alnarp. Previous studies on breeding lines (Öland 5 and Öland 8 ) from the cultivar 'Ölands' have revealed both high and low content lines [16], which indicate presence of some genetic variation for carotenoids content in this wheat landrace. The reason for the low content of lutein in some of the wheat in this study is, though, a general low content in carotenoids. Thus, for all the evaluated wheat cultivars in the present study, lutein represented $70-95 \%$ of the total 
carotenoids, thereby corresponding to previous results [16]. For spring rye ('Jusso'), the relative content of lutein was $60-70 \%$ of the total carotenoids and relatively high contents of $\beta$-carotene and $\beta$-cryptoxanthin was also noted. Similarly as described previously [28], the barley cultivars evaluated here showed low levels of lutein (40-55\% of the total carotenoids), and zeaxanthin was a major component (40-55\% of the total carotenoids).

In the present study, $\mathrm{R}^{2}$ values were used to explain the percentage of explanation of different sources (cultivar, location, and their combinations) on content of total and various types of carotenoids, similarly to what has been reported in previous studies [9,32-34]. Here, the combination of cultivars and localities was found to have the highest percentage of explanation for the amount of all the various carotenoids compounds, i.e., to have an effect of content, the highest effect is obtained by a combination of genotype and the environment. This clearly indicates a local adaptation of the landraces in the present study. Such an adaptation has been developed over long periods of time to a certain region of cultivation, resulting per definition in the specificity of a landrace $[43,44]$. Such specificity contributes opportunities to produce unique quality grains within a certain region by the use of a specific landrace. However, current plant breeding strategies are often focusing on the production of high yielding genotypes producing similar quality over a large range of environments (cultivation locations and years), thereby contributing food security independent of environment [45]. Thus, unique qualities might be lost on the pace towards high yield and food security. In the present study, we evaluated also the stability in carotenoid content of the landraces between and within localities and the genotypes showed clear variation in this character. Previous studies on stability for minerals content in the same material have also indicated differences in stability $[9,46]$. Most of the genotypes showed limited stability for all carotenoids compounds between and within cultivation environments (localities) although the different barley genotypes investigated tended to show higher stability than the other cereal genotypes evaluated.

The lipophilic carotenoids ( $\alpha$-carotene, $\beta$-carotenes and $\beta$-cryptoxanthin) are precursors of vitamin A, which is essential for cell growth, fetal development, and immune functions [47]. Deficiency of vitamin A leads to increased infections risks and pregnancy complications [48] and may even lead to childhood death [48]. The present study, and also previous ones [42], shows that the level of pro-vitamin A compounds in wheat, and also in rye and barley, is generally low and, therefore, consumption of animal products, and some fruits and berries $[11,49,50]$ are recommended for sufficient vitamin A content in the diet. However, cereals are instead rich in other carotenoids than those being precursors of vitamin A. Lutein is the most abundant carotenoid in wheat and barley [18,34,39], which was also confirmed here, while according to this study, zeaxanthin was the pre-dominant carotenoid in rye. Lutein has been ascribed as having an important function for the eye retina and some studies have also indicated an impact in preventing cardiovascular diseases and cancer [51]. Due to the high daily consumption of cereals in large regions in the world, lutein content in the cereals may play an important role for sufficient intake although other sources, e.g., green leafy vegetables [50] may have higher contents. Recommendations of daily intake of lutein is scarce, although a previous study calculating needed intake from serum lutein concentrations in humans, came up with a suggestion of an average intake of lutein + zeaxanthin of $1101 \pm 838 \mu \mathrm{g} /$ day [16]. From these calculations, the consumption of $130 \mathrm{mg}$ wheat per day should be sufficient to cover the daily need of lutein if the highest value genotypes of this study were selected.

\section{Conclusions}

Locally adapted cereals showed a large variation in carotenoid contents among genotypes and over cultivation locations. Some of the genotypes presented levels of total carotenoids in parity with the highest levels previously reported in einkorn, durum, and purple wheat. Lutein was the major carotenoid in wheat and rye, the latter also with high levels of $\beta$-carotene and $\beta$-cryptoxanthin, while zeaxanthin was the dominating carotenoid in barley. Most of the locally adapted cereals evaluated showed a clear local adaptation 
with little stability in carotenoids content especially between cultivation locations. This impair significant opportunities to produce local high value cereals for certain local produce of high value, high nutrition food products. However, the local adaptation also limits conventional breeding opportunities with a variety performing similar over a broad range of environments.

Supplementary Materials: The following are available online at https:/ /www.mdpi.com/article/10 .3390/pr9050783/s1, Figure S1: Example of a representative HPLC chromatogram (showing Diamant Brun from Alnarp), with the four peaks of the different carotenoids in the samples indicated by their designations.

Author Contributions: All authors have contributed in the conceptualization, executing, compiling data and write up of the study. All authors have read and agreed to the published version of the manuscript.

Funding: EkoForsk, and the Ekhaga foundation Sweden for project grants and Higher Education Commission, Pakistan for financial support to Abrar Hussain.

Institutional Review Board Statement: Not applicable.

Informed Consent Statement: Not applicable.

Data Availability Statement: Not applicable.

Acknowledgments: We are also thankful to Maria Luisa Prieto-Linde for technical assistance during the chemical analysis.

Conflicts of Interest: The authors declare no conflict of interest.

\section{References}

1. Shiferaw, B.; Smale, M.; Braun, H.-J.; Duveiller, E.; Reynolds, M.; Muricho, G. Crops that feed the world 10. Past successes and future challenges to the role played by wheat in global food security. Food Secur. 2013, 5, 291-317. [CrossRef]

2. FAO Food and Agriculture Organization of the United Nations. FAOSTAT Database; FAO: Rome, Italy, 2019.

3. Pena-Bautista, R.J.; Hernandez-Espinosa, N.; Jones, J.M.; Guzman, C.; Braun, H.J. Wheat-based foods: Their global and regional importance in the food supply, nutrition and health. Cereal Foods World 2017, 62, 231-249. [CrossRef]

4. Save and Grow in Practice: Maize Rice Wheat. A Guide to Sustainable Cereal Production. In Food and Agriculture Organization of the United Nations (FAO); FAO: Rome, Italy, 2016; ISBN ISBN 978-92-5-108519-6.

5. Andersen, V.; Bar, E.; Wirtanen, G. Nutritional and Health Aspects of Food in Nordic Countries; Academic Press: Berlin/Heidelberg, Germany, 2018; ISBN 978-0-12-809416-7.

6. Pinheiro, M.A.A.; Bebeli, P.J.; Bettencourt, E.; Costa, G.; Dias, S.; Dos Santos, T.M.M.; Slaski, J.J. Cereal landraces genetic resources in worldwide GeneBanks. A review. Agron. Sust. Dev. 2013, 33, 177-203.

7. Schmidt, S.B.; George, T.S.; Brown, L.K.; Booth, A.; Wishart, J.; Hedley, P.E.; Martin, P.; Russell, J.; Husted, S. Ancient barley landraces adapted to marginal soils demonstrate exceptional tolerance to manganese limitation. Ann. Bot. 2019, 123, 831-843. [CrossRef] [PubMed]

8. Hussain, A.; Larsson, H.; Kuktaite, R.; Johansson, E. Mineral composition of organically grown wheat genotypes: Contribution to daily minerals intake. Int. J. Environ. Res. Public Health 2010, 7, 3442-3456. [CrossRef] [PubMed]

9. Moreira-Ascarrunz, S.G.; Larsson, H.; Prieto-Linde, M.L.; Johansson, E. Mineral nutritional yield and nutrient density of locally adapted wheat genotypes under organic production. Foods 2016, 5, 89. [CrossRef]

10. Shafie, F.A.; Rennie, D. Consumer perceptions towards organic food. Procedia Soc. Behav. Sci. 2012, 49, 360-367. [CrossRef]

11. Johansson, E.; Hussain, A.; Kuktaite, R.; Andersson, S.C.; Olsson, M.E. Contribution of organically grown crops to human health. Int. J. Environ. Res. Public Health 2014, 11, 3870-3893. [CrossRef] [PubMed]

12. Underwood, T.; McCullum-Gomez, C.; Harmon, A.; Roberts, S. Organic agriculture supports biodiversity and sustainable food production. J. Hunger Environ. Nutr. 2011, 6, 398-423. [CrossRef]

13. Liu, R.H. Whole grain phytochemicals and health. J. Cereal Sci. 2007, 46, 2017-2219. [CrossRef]

14. Ndolo, V.U.; Beta, T. Distribution of carotenoids in endosperm, germ and aleurone fractions of cereal grain kernels. Food Chem. 2013, 139, 663-671. [CrossRef] [PubMed]

15. Mellado-Ortega, E.; Hornero-Méndez, D. Carotenoids in cereals: An ancient resource with present and future applications. Phytochem. Rev. 2015, 14, 873-890. [CrossRef]

16. Hussain, A.; Larsson, H.; Kuktaite, R.; Olsson, M.E.; Johansson, E. Carotenoid content in organically produced wheat: Relevance for human nutritional health on consumption. Int. J. Environ. Res. Pub. Health 2015, 12, 14068-14083. [CrossRef] [PubMed]

17. Zhou, K.; Yin, J.J.; Yu, L. Phenolic acid, tocopherol and carotenoid compositions, and antioxidant functions of hard red winter wheat bran. J. Agric. Food Chem. 2005, 53, 3916-3922. [CrossRef] 
18. Moore, J.; Hao, Z.; Zhou, K.; Luther, M.; Costa, J.; Yu, L. Carotenoid, tocopherol, phenolic acid and antioxidant properties of Maryland-grown soft wheat. J. Agric. Food Chem. 2005, 53, 6649-6657. [CrossRef] [PubMed]

19. Leenhardt, F.; Lyan, B.; Rock, E.; Boussard, A.; Potus, J.; Chanliaud, E.; Remesy, C. Genetic variability of carotenoid concentration, and lipoxygenase and perioxidase activities among cultivated wheat species and bread wheat varieties. Eur. J. Agron. 2006, 25, 170-176. [CrossRef]

20. Konopka, I.; Czaplicki, S.; Rotkiewicz, D. Differences in content and composition of free lipids and carotenoids in flour of spring and winter wheat cultivated in Poland. Food Chem. 2006, 95, 290-300. [CrossRef]

21. Granado, F.; Olmedilla, B.; Blanco, I. Nutritional and clinical relevance of lutein in human health. Br. J. Nutr. 2003, 90, 487-502. [CrossRef]

22. Ma, L.; Lin, X.-M. Effects of lutein and zeaxanthin on aspects of eye health. J. Sci. Food Agric. 2010, 90, 2-12. [CrossRef] [PubMed]

23. Saini, R.K.; Keum, Y.S. Carotenoid extraction methods: A review of recent developments. Food Chem. 2018, 240, 90-103. [CrossRef]

24. Kopec, R.E.; Cooperstone, J.L.; Cichon, M.J.; Schwartz, S.J. Analysis Methods of Carotenoids. In Analysis of Antioxidant-Rich Phytochemicals; Wiley-Blackwell: Oxford, UK, 2012; pp. 105-148. ISBN 9780813823911.

25. Granado, F.; Olmedilla, B.; Gil-Martinez, E.; Blanco, I. A Fast, Reliable and Low-cost Saponification Protocol for Analysis of Carotenoids in Vegetables. J. Food Comp. Anal. 2001, 14, 479-489. [CrossRef]

26. Abdel-Aal, E.-S.M.; Young, J.C.; Rabalski, I.; Hucl, P.; Frgeau-Reid, J. Identification and quantification of seed carotenois in selected wheat species. J. Agric. Food Chem. 2007, 55, 787-794. [CrossRef] [PubMed]

27. Hidalgo, A.; Brandolini, A.; Pompei, C.; Piscozzi, R. Carotenoids and tocols of einkorn wheat (Triticum monococcum ssp. monococcum L.). J. Cereal Sci. 2006, 44, 182-193. [CrossRef]

28. Paznocht, L.; Kotíková, Z.; Sulc, M.; Lachman, J.; Orsák, M.; Eliásová, M.; Martinek, P. Free and esterified carotenoids in pigmented wheat. Tritordeum and barley grains. Food Chem. 2018, 240, 670-678. [CrossRef] [PubMed]

29. Tang, Y.; Yerke, A.; Sang, S. Oats Whole Grains and Their Bioactives: Composition and Health; Johnson, J., Wallace, T., Eds.; John Wiley \& Sons Ltd.: Hoboken, NJ, USA, 2019.

30. Adams, D.C.; Salois, M.J. Local versus organic: A consumer preferences and willingness-to-pay. Renew. Agric. Food Syst. 2010, 25, 331-341. [CrossRef]

31. Klopcic, M.; Verhees, F.J.H.M.; Kuipers, A.; Kos-Skubic, M. Consumer preceptions of home made, organic, EU certified, and traditional local products in Slovenia. In Consumer Attitudes to Food Quality Products; Klopcic, M., Kuipers, A., Hocquette, J.F., Eds.; EAAP_European Federation of Animal Science; Wageningen Academic Press: Wageningen, The Netherlands, 2013 ; Volume 133.

32. Fratianni, A.; Caboni, M.F.; Irano, M.; Panfili, G.A. Critical comparison between traditional methods and supercritical carbon dioxide extraction for the determination of tocochromanols in cereals. Eur. Food Res. Technol. 2002, 215, 353-358. [CrossRef]

33. Hussain, A.; Larsson, H.; Olsson, M.E.; Kuktaite, R.; Grausgruber, H.; Johansson, E. Is organically produced wheat a source of tocopherols and tocotrienols for health food? Food Chem. 2012, 132, 1789-1795. [CrossRef]

34. Panfili, G.; Fratianni, A.; Irano, M. Improved normal-phase high-performance liquid chromatography procedure for the determination of carotenoids in cereals. J. Agric. Food Chem. 2004, 52, 6373-6377. [CrossRef]

35. Malik, A.H.; Kuktaite, R.; Johansson, E. Combined effect of genetic and environmental factors on the accumulation of proteins in the wheat grain and their relationship to bread-making quality. J. Cereal Sci. 2013, 57, 170-174. [CrossRef]

36. Vazquez, D.; Berger, A.; Prieto-Linde, M.L.; Johansson, E. Can nitrogen fertilization be used to modulate yield, protein content and bread-making quality in Uruguayan wheat? J. Cereal Sci. 2019, 85, 153-161. [CrossRef]

37. Mukamuhirwa, A.; Persson Hovmalm, H.; Ortiz, R.; Nyamangyoku, O.; Prieto-Linde, M.L.; Ekholm, A.; Johansson, E. Effect of intermittent drought on grain yield and quality of rice (Oryza sativa L.) grown in Rwanda. J. Agron. Crop Sci. 2020, 206, 252-262. [CrossRef]

38. Ross, S.M. Introductory Statistics; Elsevier Inc.: Oxford, UK, 2010.

39. Okarter, N.; Liu, C.S.; Sorrells, M.E.; Liu, R.H. Phytochemical content and antioxidant activity of six diverse varieties of whole wheat. Food Chem. 2010, 119, 249-257. [CrossRef]

40. Adom, K.K.; Sorrells, M.E.; Liu, R.H. Phytochemicals and antioxidant activity of wheat varieties. J. Agric. Food Chem. 2003, 51, 7825-7834. [CrossRef] [PubMed]

41. Lachman, J.; Hejtmánková, K.; Kotíková, Z. Tocols and carotenoids of einkorn, emmer and spring wheat varieties: Selection for breeding and production. J. Cereal Sci. 2013, 57, 207-214. [CrossRef]

42. Fratianni, A.; Giuzio, L.; Di Criscio, T.; Zina, F.; Panfili, G. Response of carotenoids and tocols of durum wheat in relation to water stress and sulfur fertilization. Food Chem. 2013, 61, 2583-2590. [CrossRef] [PubMed]

43. Ceccarelli, S. Wide adaptation: How wide? Euphytica 1989, 40, 197-205.

44. Wolfe, M.S.; Baresel, J.P.; Desclaux, D.; Goldringer, I.; Hoad, S.; Kovacs, G.; Löschenberger, F.; Miedaner, T.; Østergård, H.; Van Bueren, E.L. Developments inbreeding cereals for organic agriculture. Euphytica 2008, 163, 323-346. [CrossRef]

45. Van Bueren, E.L.; Jones, S.S.; Tamm, L.; Murphy, K.M.; Myers, J.R.; Leifert, C.; Messmer, M.M. The need to breed crop varieties suitable for organic farming using wheat, tomato and broccoli as examples: A review. Njas-Wagen J. Life Sci. 2010. [CrossRef]

46. Johansson, E.; Prieto-Linde, M.L.; Larsson, H. Locally adapted and organically grown landrace and ancient spring cereals-A unique source of minerals in the human diet. Foods 2021, 10, 393. [CrossRef]

47. Rao, A.V.; Rao, L.G. Carotenoids and human health. Pharmacol. Res. 2007, 55, 207-216. [CrossRef]

48. Zile, M.H. Vitamin A and embryonic development: An overview. J. Nutr. 1998, 128, 455s-458s. [CrossRef] [PubMed] 
49. Andersson, S.C.; Olsson, M.E.; Johansson, E.; Rumpunen, K. Carotenoids in Sea Buckthorn (Hippophae rhamnoides L.) Berries during Ripening and Use of Pheophytin a as a Maturity Marker. J. Agric. Food Chem. 2009, 57, 250-258. [CrossRef] [PubMed]

50. Saini, R.K.; Nile, S.H.; Park, S.W. Carotenoids from fruits and vegetables: Chemistry, analysis, occurrence, bioavailability and biological activities. Food Res. Int. 2015, 76, 735-750. [CrossRef] [PubMed]

51. Osganian, S.K.; Stampfer, M.J.; Rimm, E.; Spiegelman, D.; Manson, J.E.; Willett, W.C. Dietary carotenoids and risk of coronary artery disease in women. Am. J. Clin. Nutr. 2003, 77, 1390-1399. [CrossRef] [PubMed] 